\title{
New and Corrected ms. readings in the Milan Glosses ${ }^{*}$ \\ Aaron Griffith and David Stifter \\ University of Vienna NUI Maynooth
}

The text of the Milan Glosses, like most of the material in the accompanying volumes, has remained largely fixed since its publication in 1903 in the Thesaurus Palaeohibernicus (Thes). Part of the FWF-funded project "A Dictionary of the Old-Irish Glosses in the Milan Codex Ambrosianus C 301 inf." involved correcting errors in that text. Some such corrections could be made simply by examining the facsimile edition (Best 1936). Numerous glosses were still too unclear, however, to allow for any reading at all, much less a correction. Thus, a research trip was undertaken by Aaron Griffith in December, 2010 to the Ambrosian Library in Milan to examine difficult glosses in the original. Frequently, unclear readings became clear under close examination (often with the help of ultraviolet light). In such cases, conjectured readings of Ascoli (18789) or Thes were sometimes confirmed, sometimes not. In other cases, glosses that were obscure to Ascoli and Thes remained obscure, even under very close examination. The purpose of this paper is to present those cases where examining the facsimile or manuscript yields a reading different from the text in Thes.

Not given here are glosses for which editorial emendations are suggested, since such changes are not based on a corrected manuscript reading, which is the focus of this article. Also not given here are corrections dealing with the presence or location of a mark of length, adding or deleting a ".i.", and simple misreadings like $u$ for $a$ or in for $m$ or $n$ for $r$ (or their inverses). These relatively minor changes have been noted in various files available online at the website for the Milan Glosses Project: http://www.univie.ac.at/indogermanistik/milan_glosses.htm.

Some of the changes offered below are available online in the just-mentioned files, but a number of them, the ones obtained by examining the original ms., are not. In any case, it seems justified to present to the scientific community all such corrections together in one place. For purposes of comparison, the ms. reading and translation from Thes are given first. Following that are the new reading and translation, with changes marked in bold so they are clear. Finally, any commentary relevant to the changes is presented after the revised reading and translation. Occasionally, it is necessary to introduce the glossed Latin text as well, which appears before all other text in the gloss.

The following make up the editorial conventions used in this article (and for the project generally). When a few letters of a word are illegible but can be confidently conjectured from context, they are written in parentheses (see 118d17 below for an example). When conjecture is not possible, the approximate number of illegible letters is indicated with colons (see $188 \mathrm{~d} 19$ below). Each colon stands roughly for the space of a letter, e.g. ::: indicates a space of illegible material approximately three letters wide. This estimation is obviously only approximate, since letters can be one to three minims wide, but it serves as a general guide to the number of letters estimated to be missing. When even this much information is undeterminable, a series of periods is

\footnotetext{
* We would like to thank Msgr. Gianantonio Borgonovo, director of the Ambrosian Library, for granting special permission for Aaron Griffith to examine the ms. with the Milan Glosses. We would also like to thank the FWF (Austrian Science Foundation; www.fwf.ac.at), which funded the project "A Dictionary of the Old-Irish Glosses in the Milan Codex Ambrosianus C 301 inf.” (project \#P19137-Go3) and the research trip to Milan.
} 
used, e.g. ........ (see 29 bi1 below). Occasionally, when only a small part of a longer gloss is cited, "etc." is used to indicate that the gloss continues before or after the excerpt given here (see glosses $23 \mathrm{~b} 5$ and $102 \mathrm{a} 15$ below). Material in angled brackets, \langle\rangle , is legible in the ms. but should be excluded for one reason or another. The reason for the exclusion is given in the commentary (see gloss $77 \mathrm{~d}_{3}$ below). Material in square brackets, [], is editorial in nature, generally suggesting a correction to the ms. reading (see, for example, $51 \mathrm{a} 8$ below). Material in curly brackets, \{\} , indicates a gloss to the gloss. That is, it appears above the line or below the line, and it presents an alternate reading to the reading of the text it glosses (see $82 \mathrm{~d} 7$ below). This is very common in the Latin text, but occurs also in the Old Irish, albeit rarely. Finally, line breaks in the Old Irish glosses are indicated with |. This notation is intended to help those attempting to follow the reading in the facsimile or in the original manuscript.

\section{3d1:}

Not in Thes

Revised: $\quad$ in maith andubso amne

is this ink good thus?

For whatever reason, Thes missed this gloss, which appears in a footnote in Ascoli (1878-9: fn. 1 to page xi, appearing on page xii). A possible alternate translation would be "Is this ink good? Indeed!" That is, one could read two sentences, a question and answer, instead of one.

14b13:

Thes: $\quad$.i. airnibu fuareir fesin boisom isintaimsir

i.e. for it is not under his own control that he was at the time.

Revised: $\quad$ i. airnibu fuareír fesin boisom isintaim(sir)|sin

i.e. for he was not under his own control at that time.

What Ascoli takes as sir of isintaimsir is on a separate line, and the $r$ looks more like an $n$. After isintaim, there is just the slightest hint of what appears to be sir. Part of the $i$ and $r$ are barely visible, and there is space for what would be $s$.

18b4:

Thes:

i. roth cruind forsandenat nacerda inlestrai ninid [leg. criad] 1. cran cruin immuambiat ocuan denum ${ }^{1}$

i.e. a round wheel on which the potters make the vessels of clay, or a round piece of wood about which they are while being made.

Revised: $\quad$.i. roth cruind forsandenat nacerda inles $\mid$ tra $\mid$ i nui $\mid 1$ cran $\mid$ cruin $\mid$ immua|mbiat ocuan | denum

i.e. a round wheel on which the potters make the new vessels, or a round piece of wood around which they (the potters) are while making them (the vessels).

As recognized in the Addenda and Corrigenda to Vol. 1, the reading in lestrai is correct, and the correction to inna lestrai (given in the main text) is unnecessary. What Ascoli and Thes read as ninid, however, is problematic. Although the writing at this point is rather faint, the first six minims are relatively clear. These minims

\footnotetext{
${ }^{1}$ Note that the Thes text given above is that of the footnotes and Addenda and Corrigenda to Vol. 1.
} 
correspond to $i$ nin (Thes) or $i$ nui (here). The last letters in Thes and Ascoli, however, are ghosts; they are the result of bleed-through from the other side of the vellum, where they represent part of lesom in gloss $18 \mathrm{c} 6$. Removing the ghost-letters leaves the revised text as suggested above, with a perfectly acceptable reading: in lestrai nui "the new vessels". Thus lestrai is the acc. sg. of a fem. iā-stem lestrae, a collective to lestar, as recognized by Thes (I.716).

\section{C12:}

Thes:

$$
\text { óndforcunn dúthrach [leg. dúthrachtach] }
$$

Not translated

Revised: $\quad$ hondforcunn dúthrach [leg. dúthrachtach]

by the desired end.

Ascoli could not read the beginning, but seems to have accepted Stokes' suggestion of ónd-. The ms., however, reads hond- (visible under UV light).

\section{3a12:}

Thes:

issamlid insin asmbertar. ut

it is thus that they are said $u t$.

Revised: $\quad$ issamlid inso asmbertar. ut it is thus that they are said $u t$.

Ascoli read this gloss correctly.

23b5:

Thes: $\quad$ etc. huare nadrucsat diriug orcuin duid iarnaerbertso $(m)$

etc. because they did not succeed in the slaying of David after they had prepared it.

Revised: $\quad$ etc. huare nadrucsat diriug orcuin duid iarnaerbertad

etc. because they did not succeed in the slaying of David after the preparation of it.

Thes' reading iarnabertso $(m)$ appears to have been based on a misinterpretation of the po- of pondus in the Latin commentary, which occurs at line end above the end of iarnabert. Ascoli suggested erbertaid, but there is no $i$ in the ms.

24b8:

Latin: $\quad$ arrecti calli ${ }^{8}$

Thes: $\quad$ inchu :: hond lurc drigthedo

Not translated.

Revised Latin: $\operatorname{arrecti}^{8}$ calli $^{8 a}$

Revised 8: $\quad$.i. inchuin|drigthe|do

i.e. of the correcter.

Revised 8a: hond lurc

from the path.

First a remark on the Latin must be made. This phrase, properly a recto calli "from the right path", appears also in 35a14, 15: á recti ${ }^{14}$ calli $^{15}$, where hond lurc once again glosses calli, but recti is glossed by indirig "of the upright one". A similar phrase also occurs in 57d5: et arrecti ${ }^{5}$ atque otqui [leg. aqui] studio, where arrecti is glossed by inchuindrichthi "of the corrected (one)". The phrase apparently gave the glossator trouble, since it was never understood absolutely correctly and was always translated 
as a genitive. Of course, the Latin itself (arrecti or a recti written for a recto) is partly to blame.

The two glosses here are extremely confused. As noted in Thes and Ascoli, the text appears to read inchu:: hondlurc drigthedo, which Ascoli suggests mixes hond lurc (translating a (recto) calli "from the (right) path") with inchumdrigthi (translating arrecti "of the one having been set up / set straight"). His interpretation is correct for glosses 34a14, 15, but not here. Here, arrecti has been wrongly interpreted as a nomen agentis.

What is clear is that hond lurc was written first, and the gloss inchuindrigthedo was written around and partly above it, with the do written further above the line with a small construe mark to indicate that it belongs with the text below it.

The in of chuindrigthedo is just barely legible under UV light. It is unclear why Ascoli suggested chumdrigthedo. He probably did not see three minims there, since he gave the text as ::, indicating that he did not see anything. He more likely made an educated guess about the correct reading based on the verb con-dirgedar "reproves" or con-dirig "id.", but did not know that ${ }^{*}$ con yields ${ }^{*}$ cun, not ${ }^{*}$ cum, before ${ }^{*} d$, cf. cuin $(d)$ chid "(act of) seeking, asking", vn. to con.dïeig "seeks, asks".

25d12:

Latin: $\quad$ quia id dicere ${ }^{12}$ Scripturæ Diuinæ sumus magistris ${ }^{13}$ eruditi

Thes: $\quad$ i. asindber i. inscriptuir diadae id. anisín nat comrorcun dunni cip e asberam

i.e. that it, to wit, the Divine Scripture says it, namely this, that we are not wrong whichever we say.

Revised: $\quad$.i. asindbeir | .i. inscr|iptuir di|adae .id. anisin nan|t comrorcon | dunini cip | e asberam

i.e. that it says it, i.e. the Divine Scripture, .id. that, that the thing, whichever it is that we say, is not an error for us.

The revised reading is relatively clear from the facsimile. The readings of nant and dunini are secure. nant looks odd on the page, with $n n$ on the line, $a$ written below the line and between the two $n$ 's, and $t$ written on the following line. The final hook on the $a$ is much higher than is usual, but the reading is not seriously in doubt. For dunini, both is are below the line, but the first one is very faint, with only its head unmistakably legible in the facsimile.

29b8:

Thes: $\quad$.i. tororansom trisindoit ingním gnís indot [leg. indoit or indóe] i.e. he signified by the arm the action that the arm does.

Revised: $\quad$.i. tororansom trisindoit ingním gnís indoe

i.e. he has signified by the arm the action which the arm does

UV light reveals very faintly that indoe is the ms. reading.

29b11:

Thes:

i. arinní gnís inpeccad 7 imbí dano inchlóine uel propter eum. i. peccatum .i. :: irro::.:.:: neut' A ....... an eum. ut scimus eum templum i.e. on account of him who does the sin and in whom there is the iniquity uel etc. 
Revised: $\quad$.i. arinní gnís inpeccad 7 imbí dano inchlói|ne uel prop|ter eum· | .i. pecca|tum .i. | ::irro | :::::neutur $\mid$ A.........::::: an | eum. ut | scimus $\mid$ eum tem|plum.

i.e. on account of him who does the sin and in whom, moreover, there is the iniquity uel etc. ... neuter...

Everything after peccatum .i. is from Ascoli. Thes does not speculate on the text, which is difficult to read, though it appears to correspond to Ascoli's conjecture. The new interpretation here is to read neut' as an Old Irish word neutur (cf. Sg. 5b7, 64a11, etc.). While the precise context is no longer available, neutur makes sense since immediately preceding it a masculine eum is equated with a neuter peccatum. At the end of the gloss, the same seems to occur with eum and templum. It appears likely that the second part of the gloss is a grammatical one, and neutur would be at home in such a gloss.

29b14:

Thes: $\quad$ i. combeth cid dath deithb(ir) . . aicsin les de ..... inpeccadsin secht immurgu ní...... innaicsin hísin .. Aliter doberat ...: : uli ........

Not translated.

Revised: $\quad$.i. combeth cid dath deithbir s: a:: aic|sin les ande|s 7 uad in|peccads|in sec|h immurgu ní| aircibea|som in|naicsin nisin.. | Aliter dobera|t anuli | s airo | he b as | inaib:: | claib so | i. inlor | e: 7 :: | la ::: | da : int |i: ::::: | ::: :: | is ::: in |dath| ni at|hihtar|tar:a| :: clitis| in parad [leg. peccad ?] | odauic | uar [leg. uad]

so there would be even a fitting color... cause / seeing with him... what is right... that sin. However he will not come upon that cause / seeing. Aliter they will give all their... the color... the sin, so that it bore them from it.

As can be observed, much of this gloss is unintelligible. The suggested readings represent a best guess, where such a one was possible. The combinations of letters often make no sense as Irish words (e.g. hihtar), but in such cases, the given reading corresponds best to what could still be read in the ms. The gloss is only as legible as it is with the help of UV light.

A further complicating factor is that the Latin commentary occasionally blurs into the gloss. The Latin commentary qui est | iniquitatis (to gloss 29b15) impinges on three lines of Irish. The superscript $i$ of qui appears to the left of peccad in in|peccads|in $\sec \mid h$, while the abbreviation for est occurs to the left in in sec and $h$ in that same passage. Further down in the same section of commentary appears facientis iniqui|tatis. The superscript $i$ of the qui in iniquitatis is to the left of dobera in dobera|t anuli|s, while the $q$ of iniquitatis appears to the left of the $t$ and $s$ in the same passage.

Despite the hopelessness of an accurate reading, at least some of the general structure of the gloss can be made out from Aliter onwards. There are four clauses that can be made out. The first starts with Aliter doberat anuli... and ends with a prepositional phrase in the dative plural: inaib:: claib so. The second phrase starts .i. inlor... [leg. ni lor...?] and probably ends with in dath. dath appears on its own line and there would appear to be room for three to five letters, but the space is blank. The third phrase begins immediately afterwards at ni at hihtar, which is the negative of a verb, probably a 3pl. passive. The final phrase can be read relatively clearly: sdauic uar [leg. uad]. 
A note on the translation: since the context is so fragmentary, aicsin, which could belong either to the vn. aicsiu "seeing" or accuis "cause", both of which are plausible here, cannot be assuredly assigned to one meaning or the other. Its translation is thus left as "seeing / cause" to reflect this ambiguity.

3ob2:

Thes:

.i. duaidbetar atafiriensom 7 atandirgi hochridiu allethe rissan ingraim atarograinn saul intan asmbeir rectos corde .i. nifil ci(nta) doib frisaul i.e. when he says recti corde they are shewn to be just and to be upright in heart as to the persecution wherewith Saul persecuted them, i.e. they are guilty of no offences against Saul.

Revised: $\quad$ i. duaidbdetar atafiriensom 7 antandirgi [leg. atandirgi] | hochridiu | alleth $\mathrm{f} \mid$ rissan in|graim | ataroig|rainn | saul | intan as $\mid$ mbeir rec|tos cor|de .i. | nifil ci|nta doib | frisaul

i.e. when he says rectos corde they are shown to be just and to be upright in [their] heart as to the persecution wherewith Saul persecuted them, i.e. there are no sins against Saul upon them.

Though both Ascoli and Thes read allethe rissan (influenced most likely by the awkward line break and the smudged nature of the line-final letter), it appears that alleth frissan is in the ms. This reading solves two problems: alleth instead of a difficult to explain allethe and frissan instead of the surprising rissan (see also McCone 1985, who views rissan as an early example of a Middle Irish development).

3ob26:

Thes:

.i. cenafortacht hodia intan mbite (isnaib fochaidib)

i.e. without help to them from God when they are (in tribulations).

Revised: $\quad$.i. cenafortacht hodia intan mbite isnaib| imnedib

i.e. without help to them from God when they are in tribulations.

Thes supplies isnaib fochaidib after intan mbite, remarking that "there may have been more on the margin, but it is now illegible". The UV light reveals isnaib imnedib.

31b7:

Latin: $\quad$ quid autem his pro talibus studiis inprecatur

Thes: $\quad$ cid...... i. achtinso (.i. ised in)so (ad)fet

what?.... i.e. but this i.e. it is this that he says.

Revised: $\quad$ cid andes .i. a|cht $|\operatorname{inn}(\boldsymbol{e})|(\boldsymbol{i})$ nso $\mid(a d) f e t$

even that which is correct (lit. the correct (thing)), i.e. but this which he (the psalmist) says (here) is (the) meaning.

Ascoli reads cid:::*:.:: i. acht inso....:: , but in his Corrigenda he suggests without comment rather oid:a::es q:: acht:::::::::::so ::fet. The reading of Thes attempts to fill in the gaps in Ascoli's reading. However, it does not look like there is nearly enough space for all of the suggested text. Although there seems to be an $s$ before the cht of acht, this is actually the ur suspension of inprecatur.

The first part of the gloss appears to answer the question posed in the Latin "what, however, does he wish upon them for such zeal?": "even that which is correct (i.e. what they deserve)". In the manuscript, the answer to this question, which is posed in the commentary, follows immediately in the form of the Psalm 12:3: "The Lord shall 
cut off all flattering lips, and the tongue that speaketh proud things." It is to this answer that the second part of the gloss refers.

31b11:

Thes: $\quad$ i. (is g)nad radat gó $i$

i.e. they usually speak lies.

Revised: $\quad$ i. epert nad ra|dat gói

i.e. saying that they do not speak falsehood.

epert is just barely legible under UV light and replaces previous suggestions.

31b25:

Thes: $\quad$ amal bite ingnimai issamlid inf(e)t som innaisndis as are the deeds, so he sets forth the speech.

Revised: $\quad$ amal bite ingnimae issamlid infet som | innaisn|dis as the deeds are, it is so that he sets forth the speech.

Both Ascoli and Thes have ingnimai, but the ms. appears to have ingnimae. The ink is no longer clear, but the middle cross-stroke of the $e$, with its characteristic long upward-slope, is still visible. The $e$ of infet is also legible.

32b18:

Thes:

.i. it ilsailm hitadbadar foisitiu apecthae doduaid

i.e. there are many psalms in which is shewn the confession of his sins by David.

Revised: $\quad$.i. it ilsailm dano hitadbadar foisitiu apecthae duduaid

i.e. there are many psalms, moreover, in which the confession of his sins by David is shown.

Neither Ascoli nor Thes include this instance of dano in the gloss, or anywhere in their compilation of the glosses. I assume that Ascoli interpreted $d \breve{a}$ as an abbreviation for datiuus, since it appears above the - $m$ - of numero, which is, in fact, dative. Since Ascoli only rarely includes these grammatical glosses in his Latin text, exactly what he thought will remain unknown. At any rate, however, it is unlikely that $d \breve{a}$ stands for datiuus, since the abbreviation for datiuus is always datĭ.

The most logical explanation is that $d \breve{a}$ is the abbreviation for dano, as occurs regularly. The word appears underneath the -ls- of ilsailm and is probably meant to follow it. The lack of construe marks is unusual, but not unprecedented. One other option is to assume that the scribe began a new line of text and that dano should follow doduaid, but the placement following ilsailm makes more sense.

Compare also gloss $32 \mathrm{~d} 24 \mathrm{a}$.

32d24a:

Not in Thes.

Revised: $\quad$ interrogatiuus dano

also a question.

This gloss does not appear anywhere in Ascoli or Thes. Presumably, dă was not recognized here as the regular abbreviation for dano. As a gloss interrogatiuus appears over the first instance of putas né in the Latin commentary, and interrogatiuus dano appears over the second instance of putas né, the gloss makes perfect sense (cf. $32 \mathrm{~b} 18$ for another instance of dano being left out). 
35C26:

Thes:

.i. anasrubart .i. mad quis est qui habitabit rl. doberad and baimchomarc (n)espach som amal sodin mani taibred domine (and) i. ....inna firinne lasacomtacht an aithesc

i.e. when he said, i.e. if he had put there only quis est qui habitabit etc., it had been an idle question then, if he had not put Domine there, i.e..... of the truth whereby the answer was sought.

Revised: i. anasrubart .i. mad quis est qui habitabit rl. doberad and | baimch|omarc nes|pach so|m amal sod|in mani| taibred | domine ant .i. |c:::: inna |firinne | lasacom|tacht an | aithesc

i.e. when he said, i.e. if it were quis est qui habitabit etc. which he had put there, it would be an idle question in that case, if he had not put Domine there, i.e. the form/questioning of the truth whereby he sought the answer.

The text from baimchomarc on is quite difficult to read, though the Thes text appears to be correct, other than ant for (and). The $n$ of nespach is visible with UV light. The reading of $c::::$ is difficult. Possibilities are cruth "the form of the truth", comarc "the questioning of the truth" or ceist "the questioning of the truth".

36b15:

Thes:

.i. airiserǵem [leg. airiserégem] file isintluch [leg. isindluc ?] toisech di confitebor ......der ......di ......ged suidiu file issin psalmo

i.e. for it is complaining that is in the first place of Confitebor (Psalm IX.)...... which is in the psalm.

Revised: $\quad$.i. airiserǵem [leg. airiserégem] file isintleth toisech $\mid$ di confite|bor ::lu|gud .i. der|chondin | diarcé|ged suidiu | file in hoc | psalmo :::::

i.e. for it is complaining that is in the first half of Confitebor (Psalm 9).... which is in this psalm.

Where Thes has luch, leth seems more probable as a reading, makes more sense in context, and is preferable in any case since it requires no emendation as opposed to $l u c h$, which requires an emendation to luc. Further, the final phrase under the reading in Thes, i.e. issin psalmo, with a switch from Irish to Latin in the middle of the prepositional phrase, is actually entirely Latin: in hoc psalmo.

The gloss is in general extremely difficult to read and while progress was made on the reading, it was not enough to allow a complete translation. Perhaps ::lugud belongs to attlugud "thanks, rejoicing" or todlugud "asking" and derchondin to derchoiniud "despairing", but it is unclear how to make this work. suidiu is also a problem as it stands, since it must have a preceding preposition, regardless of whether it belongs to suide "seat" or side "the aforementioned". There is maybe enough room for the preposition $i^{N}$ "in". Alternately, the reading could perhaps be :::dia "God". The marks after psalmo are unclear, but are likely a word.

A note on the content is also in order. The Latin commentator made a mistake when he claimed that the present psalm (Psalm 15 is being glossed) and Psalm 9, the Confitebor, share subject matter: thanks to God for the destruction of enemies. That is true for the first half of Psalm 9, but it is not true for Psalm 15. Since the first half of Psalm 9 contains thanks to God, it obviously does not contain a complaint, as suggested by this gloss. The complaint appears rather in the second half of the Psalm, 
after verse 22 of the Vulgate (Psalm 10 in the modern numbering). The glossator appears simply to have made a mistake.

Perhaps the glossator even realized his mistake in attributing complaining to the first half of psalm 9 and tried to correct it. The second half of the gloss may then be this correction. Since tlugud very likely is attlugud "thanks", he may be attempting to say that it is acutally thanks (attlugud) which is here ( $i$ suidiu), i.e. which is in this psalm (file in hoc psalmo). Unfortunately, given the state of the ms., we can say no more.

37c16:

Thes: $\quad$ las $(e)$.i. e...im...th donemadath...mani cathaiged occa ali sisa (?) inna cestae sin les dominus pars rl.

leg: $\quad$ las(e) $\quad$ i. ce immurgu cruth (?) donémad athir mani cathaiged occa. isí alisis inna cestae sin les dominus pars rl.

when, i.e. or how could he defend his land if he did not fight in doing so? This is his $\lambda \dot{v} \sigma \iota \varsigma$ of that question, to wit, Dominus pars etc.

Revised: $\quad$.i. amal $\boldsymbol{b a}(\boldsymbol{d}) \mid \boldsymbol{n}$-ex hoc (uer|s)u in $\boldsymbol{c}(\boldsymbol{r u}) \mid$ th done $\mid$ madath $\mid$ ir mani $\mid$ cathaiged | occae is | si íc inna |cestae | sin les dominus | pars rl.

i.e. as if it were from this verse how he would have defended his land if he did not fight for it. This is the solution to that question for him: Dominus pars etc.

The gloss as given here is quite different from the suggested readings of Ascoli and Thes, but the UV light reveals just enough to allow the reading above.

38d15-16, 18:

Thes 15-16: amal is onchumscugud |.i. amal | chon nos|caigth|er tene | as by the motion, i.e. as fire is moved.

Thes 18: $\quad$.i. setir $\mid 7$ astoi|ther oc |imfolung | indoír pro|mthi sic im|im forla|ingisse prom|the tris|nafochai|di

i.e. men blow and stir (?) in making proved gold, sic Thou hast made me proved through afflictions.

Revised: $\quad$ Text remains the same. The glosses are simply combined (see below). Ascoli and Thes both give the gloss from .i. setir on as a separate gloss (18), attaching it to the word inuinisti. In fact, it is part of gloss $15-16$, since it immediately follows from the end of (former) gloss 16 in sense and on the ms. page. It is generally the practice of Ascoli to attach a gloss to the last word of the phrase, even when it appears above an earlier word. In this case, it appears that since the second half of gloss 18 refers to the whole sentence, he attached it to the last word of the sentence.

39c22:

Thes: $\quad$ etc. i. amal donemat eoin asuthu arinderoime som dia samlid etc. namely, that, as birds protect their young, so God may protect him. Revised: $\quad$ etc..i. amal don|emat eoin $\mid$ asuthu $\mid$ arinde|roima $\mid$ som dia $\mid$ samlid etc. i.e., as birds protect their young, may God protect him thus.

This correction is only visible under UV light.

4ob7:

Thes:

.i. imaisndisse 1. ollasndisse .i. $l(a ́ n)$ di cech thrup...... alaile di.....s $d u$ (tha)idbsin innan guas 7 in soirtha hodia. 
i.e. declared on both sides, or declared emphatically, i.e. full of every figure ......... to set forth the perils and the deliverance by God.

Revised: $\quad$.i. imaisndisse 1. ollasndis|se .i. | lam [leg. lan] di | cech thrup | d:l :la::: | bu:s [leg. dúal 7 lan di búas] $d u \mid \boldsymbol{t h}(\boldsymbol{a i})$ dbsin $\mid$ innan guas $\mid>$ in soirtha $\mid$ hodia.

i.e. declared on both sides, or declared emphatically, i.e. full of every fitting figure and full of knowledge for setting forth the perils and the deliverance by God.

Thurneysen's suggestion of lán is likely semantically, but lam or lain would seem more justified by the ms. Between thrup and alaile is room for up to four letters, and between $b u$ or $b a$ (Thes' and Ascoli's di) and $s d u$ is space for up to two letters. The alaile in Ascoli and Thes is not totally legible. Clear is la and that there is a long strike in the next-to-last letter. As alaile seems to be totally out of place in the gloss, a different solution is suggested here.

It appears that the scribe interpreted amfaticus as a compound of amphi- and fatus and glossed it accordingly. imaisndisse is an etymological gloss: amphi- $=i m m$ - and fatus = aisndisse. ollaisndisse, with oll "great, ample", is then an attempt to give a better translation. The rest of the gloss is then further explanation.

4ob9:

Thes: $\quad$ i. amal as már agalar de 7 as comacus du bas 7 as nephimgabthi

i.e. as his distress is great therefrom, and is nigh unto death and is unavoidable.

Revised: $\quad$.i. amal as már agalar de 7 as co|macus du | bas 7 as | neph|imgab|the

i.e. as his sickness is great because of it, and is close to death, and is not avoided.

The form is faintly, but clearly, legible with UV light. Its interpretation is somewhat difficult.

44c12:

Thes: $\quad$ i. inmachtad [leg. inmacdacht] in dentar cech semplae 7 cech báis

i.e. the boyhood in which every silliness and every folly is done.

Revised: $\quad$.i. inmactad [leg. inmacthad] | in dentar | cech semp|lae 7 cech|báis

i.e. of the boyhood in which every silliness and every foolishness is done.

Thes suggests that the ms. has machtad, which should be read macdacht. The ms. actually has mactad, as in Ascoli. There is a somewhat obscure sign above the $c$ in mactad, which Thes apparently took to be an $h$, yielding machtad. I take it rather to be a mark of construal connecting the gloss wih eetatis in the Latin. This seems likelier to me, since the sign does not especially resemble an $h$, and otherwise the mark of construal above the Latin $x$ tatis would have no correspondence in the Old Irish.

It is assumed here, following Ascoli, that mactad represents macthad, the gen. sg. of an otherwise unattested *macthu "boyhood", an abstract of the same formation as oítiu, gen. oited "youth".

44c20:

Thes: $\quad$ i. amal dunthlaichiursa cucut a doe ar(duai)d thufortacht

i.e. as I ask of Thee, O God, says David, Thy help. 
Revised: $\quad$.i. amal dun|thluichi|ursa cu|cut a doe | orren dam | thufor|acht [leg. thufortacht]

i.e. as I ask it of You, O God: give Your (sg) help to me.

The text is just legible with UV light. Somewhat difficult is dam thuforacht. The lenition of thu $=$ do 2 sg poss. pron. is odd. Other interpretations are more problematic, however.

45b13:

Thes:

.i. mochland sa ón

i.e. my children.

Revised: $\quad$.i. mochlanda sa ón

i.e. that is, my offspring.

Thes gives the text as mochland, although Ascoli has mochlanda, which is clear from the ms.

45b15-16:

Latin:

ADNUNTIABUNT CALII5 IUSTITIAM.. ut pari studio in mores ${ }^{16-17}$ instituant ${ }^{18}$.

Thes: $\quad$ i. bestatu forchanat .i. inna nime fadesin 1 . it 〈ind inna nime ata forcitlaidi

i.e. morality which they teach, i.e. the heavens themselves, that is, it is the heavens that are teachers.

Revised: $15 \quad$.i. inna nime $\mid$ fadesin $\mid$ 1. it $\langle$ ind $\rangle \mid$ inna nime ata forcit $\mid$ laidi.

i.e. the heavens themselves, that is, it is the heavens that are teachers.

Revised: 16 .i. bestatu forchanat .

i.e. morality which they teach.

The two glosses have been run together in the ms., as noted in Thes and Ascoli, but the suggestion of Thes does not make sense. The editors of Thes state that the glosses appear thus (below left):

$$
\begin{aligned}
& \text { i. inna nime } \\
& \text { fadesin }
\end{aligned}
$$

i. bestatu forchanat 1 . it ind

inna nime ata forci

tlaidi .i. inna nime

ADNUNTIABUNT CÆLI fadesin

.i. bestatu forchanat 1 . it ind inna ni $\mathrm{me}$ ata forci

STUDIO IN MORES IN tlaidi

The interpretation in Thes might appear reasonable, but their representation of the glosses (above left) is not totally accurate. Correcting the mistakes and adding the Latin text in relation to the Old Irish gloss (above right) allows a more accurate interpretation of the glosses. It becomes clear that gloss 16, i. bestatu forchanat, was actually written first. Gloss 15 was then written around both gloss 16 and around the Latin text.

Here, glosses 15 and 16 are given separately, which allows for a better interpretation. The ind is superfluous, most likely a mistake (as also in 45d19).

48c34:

Thes:

i.e. other names that David gives to them there. 
Revised: $\quad$.i. ilanman dom $\mid$ ber doib $\mid \boldsymbol{d u}(\boldsymbol{a}) \boldsymbol{i d}$

i.e. many names which David gives to them.

duid or duaid is partially legible (and not abbreviated), but there is absolutely no trace of and.

51a8:

Thes: $\quad$.i. hó lorc dromma delc. [leg. lorc dromma nó delc] the backbone, or a thorn.

Revised: $\quad$.i. delc hó [leg. nó] lorc dromma

i.e. thorn, or spine.

Ascoli and Thes give the text as .i. hó lorc dromma delc. delc. appears below the rest of the gloss, which begins .i. hó. The single raised dots after delc and before hó are to be read as construe marks. The $o$ of hó is below the line, which is unusual for $o$ (though not for other letters, such as $a$ or $i$ ).

It appears that something (possibly ł) was written before delc and then erased. This all gives the impression that .i. lorc dromma was written first, and then below it $\downarrow$ delc was added. Then, the scribe changed his mind, erased the 1 , and added hó before lorc. This hó could very well have been written over the original .i., since the left hasta of the $h$ would be a perfect $i$. Of the two periods of .i., the first one became the construe mark linking delc to hó and the second one was written over by the bow of the $h$. Finally, a second .i. was added after the first was written over.

$51 \mathrm{c2}$ and 51c3:

Thes 2: $\quad$ i. aircech ceneliu ciuil honid techtae molad dó do ber som ani as chithara

i.e. he puts cithara for every kind of music with which it is fitting to praise God.

Thes 3: $\quad$ as beir hondaisndís

he says by way of preface.

Revised 2: $\quad$.i. aircech ceneliu ciuil honid techtae mollad dó do ber | som ani as chi|thara as beir

i.e. for every kind of musical instrument with which the praise of God is fitting, he puts the cithara which he mentions.

Revised 3: hondaisndís

for the explanation.

Thes places as beir with gloss 3. While both glosses make sense under that reading, Ascoli's reading (given above) is consistent with the ms. Gloss 3 (hondaisndis) appears to have been written first, with Gloss 2 then written afterwards, as indicated by the fact that there is a break in gloss 2 between ciuil and honid caused by the accent of hondaisndis restricting the available space. Reading the ms. as Thes does is nearly impossible, not for reasons of sense, but because asbeir is simply nowhere near hondaisndís.

53c14:

Thes: $\quad$.i. for (d)ab cech ansa ol duaid etc.

i.e. I will teach you, says David etc.

Revised: $\quad$.i. fortab|cech ansa $\mid$ ol duaid etc.

i.e. "I will teach you (pl)", says David etc. 
Thes (Suppl. p. 16, note to p. 168) accepts a suggestion of Bergin's and fills in the missing text as above. Examining the ms. with UV light confirms Bergin's surmise.

54b30:

Thes:

arinchensa(i) (.i. ní comt)acht som nibed uilliu duthabairt foraib som difochaid indaas indaricc som foir som

for the gentleness, i.e. he asked not that any more tribulation should be inflicted on them than......

Revised: $\quad$ arinchensai .i. airní comtacht som nibed uilliu duthabairt foraib som difochaid indaas indaricc som [leg. indaas aricc som] foir som

for the gentleness, i.e. for he did not ask that any more suffering should be inflicted on them than he finds on him.

The gloss is just legible with UV light.

The ms. reading of the last phrase can hardly be correct as it stands. The correction offered here is the simplest and most likely correction, though it should be noted that -som appearing twice in the same clause and referring to the same person is highly unusual.

54c18:

Thes: $\quad$.i. hure [leg. huare] asbered heremias friusom fesin arangnetis d(eg)nimu ar(du)ecomnacht dia incathraig hilama cald. 7 hure [leg. huare] noteged echtarchaig [leg. -cathraig] .....n dilmai( $n)$ domm.....som b....eg..nach.. d..... immurgu noteged som 7 no .....disiu.,

i.e. because Jeremiah used to say to them themselves that they should do good works, since God had delivered the city into the hands of the Chaldees and because he used to go outside the city......

Revised: i. hure [leg. huare] as|bered here|mias friu|som fesin ar|angnetis $\boldsymbol{d e}(\boldsymbol{g}) \mid$ nimu ardu|ecomnacht | dia incath|raig hilama | cald. 7 hure | noged echta|rchaig [leg. huare noteged echtarchathraig] 7 ba $\mid$ ndilmain do | dommuintis|som ba (dia)m|mrath no|teg [leg. noteged] noch ba $\mid$ duloig biid immurgu noteged | som 7 nibu d(i)ndisin

i.e. because Jeremiah used to say to them themselves that they should do good works, since God had delivered the city into the hands of the Chaldeans. And because he used to go outside the city and it was unrestrained for him, they used to think that it was for their betrayal that he used to go, and yet, however, it was for the purchase of food that he used to go; and it was not because of that (i.e. for betrayal).

Though there are some difficulties with the text even under UV light, much can be read here that was obscure to Ascoli and Thes. The reading of ba (dia)mmrath is especially difficult. If this is indeed the correct reading, the $i$ would have to be subscripted, since there is otherwise not enough room for all the letters. The other possible reading would be $b a(d i) m m r a t h$ (i.e. bad $i m$-mrath) "it was (in)to betrayal", but this seems less preferable.

The story related here is a misinterpretation of the Vulgate. In Jeremiah 37:11, the prophet leaves the city to take possession of property he had bought (in chapter 32): egressus est Hieremias de Hierusalem ut iret in terram Beniamin et divideret ibi possessionem in conspectu ciuium "Jeremiah went out from Jerusalem in order to go 
into the land of Benjamin to receive his portion (of land) there among the people". ciuium "of the people" was misunderstood as cibum "food", leading to an erroneous interpretation in the commentary: Heremias quoque ${ }^{18}$, cum diceretur ${ }^{19}$ obsessa \{hirusalem\} ciuitate ad Caldeos $^{20}$ transfugere ${ }^{21}$, qui ad mercendos cibos pergebat "also Jeremiah, since he, with the city under siege, was said to go over to the Caldeans and was proceeding to buy food". This interpretation was taken up in the Old Irish. To reflect ad mercendos cibos, the glossator used lóg biid "purchase of food", with the less common, though well attested, meaning "purchase-price, act of buying" for lóg (DIL L-184.3ff.).

\section{4c36:}

Thes:

indoilb(thid .i. ho)dolbud sainr(iud)

figuratively, i.e. by a particular figure.

Revised: $\quad$ indoilb|thid .i. ho|dolbud sain $\mid($ trui $) \boldsymbol{p}$

figuratively, i.e. by the formation of a particular figure.

A very faint trace of a construe mark connects this gloss to figurate, not Ebreca, as Thes (see Addenda and Corrigenda, Vol I, p. 721) and Ascoli have it. Though the gloss now precedes gloss 35 , the gloss numbering will remain the same, so as not to cause confusion.

The gloss is found in the lower left margin beside the last two lines of the Latin commentary and it is legible only under UV light, though even so, the last half of the last word is still obscure. The line breaks after sain, and following that all that is visible is a $p$ and the faintest outline of the $t$. I assume that the end of the word is trop.

According to Ascoli the $r$ of sainriud is legible. It is unclear what he saw, i.e. whether he saw the $r$ of truip or interpreted some other part of truip as an $r$.

56b25:

Thes: $\quad$ indomataid [leg. indommatad]

Not translated.

Revised: indommatad

of the poverty.

The ms. actually has the reading suggested by Thes.

56b33:

Thes:

dechur tra tadbat som isindisiu etir aní as emulari 7 aní as zelaueris .i. intan asndéut téit an emulari át són imní nad techtai féin 7 bís lannach naile azelaueris immurgu át són imní notechtai fein arna(c)hróthechta nachaile hicuturummus frit. Aliter asber. mailgaimrid biid chiall intamlae is indí a(s z)elaueris amal rundgab is indi as emulari 7 ni dui...... ade fricheill ints(a)ilm cenid deni stoirier

he shews then herein the difference between emulari and zelaueris, i.e. when it applies to jealousy, emulari is jealousy about a thing that thou dost not possess and that some other has, zelaueris, however, is jealousy about a thing that thou possessest thyself, that another may not possess it equally with thee. Aliter, Mailgaimrid says, there is the sense of imitation in zelaueris as there is in emulari. And that is not... . . to the sense of the psalm, though the commentator does not make it so. 
Revised: dechur tra | tadbat som | isindisiu et|ir aní as emu|lari 7 aní as | zelaueris | i. intan asndéut téit an emulari oét són imní nad techtai féin 7 bís lannach naile azelaueris immurgu | dét són im|ní notech|tai fein | arnachró|thechta | nachaile | hicuturum|mus frit. | Aliter asber. m|ailgaimrid | biid chiall in|tamlae is | indí a[s] zela|ueris amal run|gab is indi $\mid$ as emulari $\mid 7$ ní diu::: | ade frich|eill intsa|ilm cenid | deni stoirier..,

[it is a] difference, then, that he shows in this between emulari and zelaueris, i.e. when it is jealousy to which emulari applies, it is jealousy about a thing that you (sg) do not possess and that some other has. [As for] zelaueris, however, that is jealousy about a thing that you yourself (sg) possess, so that another may not possess it equally with you (sg). Aliter, Mailgaimrid says, there is the sense of imitation in zelaueris as there is in emulari. And that may not... to the sense of the psalm, though the commentator does not do it.

For rungab, Thes has rundgab. There is no space in the ms. for the - $d$-indicated in Thes, so Ascoli's reading rungab is correct.

The difficult-to-read section is difficult even under UV light. Thes' ni dui... could also be read ní diu or possibly nídin, and in the illegible gap there is space for three or four letters, with -gna- or -gru- seeming most probable. The readings possible from the ms. do not yield a fitting Old Irish word (.dingra 3sg. subjunctive to do.ingair "calls (by a name)" is not especially appealing). Taking ade on the following line as part of an ending to a past passive participle does not yield a better reading either. Reading dingba( $i$ )de to do.ingaib "fits, is a match" would require that the $r / n$ interpretation of the letter in question to be incorrect; moreover, the meaning "fits, is a match" is a somewhat later development. Since no satisfactory solution is available, none will be adopted here.

58b2:

Thes: $\quad$.i. inna ball [leg. innam ball] tuisten

i.e. of the members of generation.

Revised: $\quad$.i. inna ball [leg. innam ball] tuisten són

i.e. namely, of the members of generation (i.e. reproductive organs).

Thes, though not Ascoli, simply left out the final word of the gloss.

6ob18:

Thes: $\quad$.i. opus .i. induloscud [leg. induleloscud]

i.e. the holocaust.

Revised: $\quad$.i. opus .i. induloscud [leg. induleloscud] són

i.e. that is, the holocaust.

Thes, though not Ascoli, simply left out the final word of the gloss.

62d13:

Thes:

sechmadachtae arthodochide .i. deduxerunt asbeirsom .i. noisduin d...s...o [leg. nochis dumdísat són]

past for future, i.e. deduxerunt that he says i.e. that is, they will lead me.

Revised: $\quad$ sechmadachtae arthodochide .i. deduxerunt asbeirsom .i. noisduin dich|::se ::: |o: [leg. nochis dumdichset són] 
past for future, i.e. deduxerunt that he says i.e. that is, they will lead me. The restoration suggested by Thes, nochis dumdisat són, is not correct, though it was plausible given the legible text they had. Sarauw's (1900: 138) conjecture is followed here.

65b11:

Thes: $\quad$ i. arthaischidetud [leg. -thaischidetaid] inmetair són

i.e. through metrical necessity

Revised: $\quad$.i. arthaischidetaid inm|etair són

i.e. that is, through metrical necessity

The suggested correction is the actual ms. reading.

67b17:

Thes: $\quad$ i. a huili chenela indomuin 1 . a maccu israhel dindamru durigeni | dia erib. 1. | a huili ch(e)|nela ata $f(o) \mid$ rbristi di|naib mach|abdib 7 di|maccaib $\mid$ israhel ol chene

i.e. $\mathrm{O}$ all ye nations of the world, or ye children of Israel, of the wonder that God did for you, or $\mathrm{O}$ all ye nations that are routed, of the Maccabees and of the Children of Israel generally.

Revised: $17 \mathrm{a}$.i. a huili chenela indomuin ł. a maccu israhel [Gloss 17b inserted here] 1. | a huili che|nela ata fo|rbristi hu|naib [leg. huanaib] mach|abdib 7 $\boldsymbol{h}(\boldsymbol{o}) \mid$ maccaib israhel ollchene

i.e. O all you ( $\mathrm{pl}$ ) nations of the world, or you (pl) children of Israel, or $\mathrm{O}$ all you (pl) nations that are crushed by the Maccabees and by the Children of Israel generally.

Revised: $17 \mathrm{~b}$ dindamru durigeni| dia erib because of the wonder that God did for you (pl).

The gloss as it appears in Ascoli and Thes is disjointed, seemingly consisting of one gloss (67b17b in the present numbering) appearing in the middle of a second gloss (67b17a in the present numbering). The two have been separated out here and been given separate numbers. Gloss $67 \mathrm{~b} 17 \mathrm{~b}$ appears to gloss MANIBUS in sense and is here attached to that word, although, as mentioned above, it is physically located within the gloss on GENTES.

67b18:

Thes: $\quad$ comtis hé tra indhuli sin forbristea [leg. forrobristea] and asbersom di hul ::: ł. it maicc israhel :un:::géni dia [leg. arandergéni dia]

these then would be those all ...... or, it is the children of Israel....

Revised: $\quad$ comtis hé tra indhuli sin forbristea and asber|som didiu hul ::: | [leg. huli

(?)] 1. it maicc is|rahel arind(er)|géni dia

so that these then would be all those who were overpowered there, who

he therefore calls "all", or, it is the children of Israel for whom God had done it.

As the gloss is extremely difficult to read, the readings suggested here are tentative. Ascoli read as Thes did, other than the last phrase, which he read as an uncertain dundrigeni dia.

68d13: 
Thes:

.i. arfenasiu [leg. arfemasiu]

Not translated.

Revised: $\quad$.i. arfemasiu

i.e. may you (sg) accept.

Following the main text of Ascoli, Thes notes that the ms. has arfenasiu, which should be read arfemasiu. As Ascoli notes in his Addenda and Corrigenda, however, the text actually reads arfemasiu.

69a4:

Thes: $\quad$ isfrisremeperthiu [leg. isfrisnaremeperthiu] i.e. it is the aforesaid.

Revised: $\quad$.i. is fers remeperthiu

i.e. in the above-mentioned verse.

The revised reading corresponds better to what is found in the ms. and makes good sense in context: quos ${ }^{4}$ hic sapientes appellat uorsu sequenti demonstrat "[those] whom he here names wise, in the subsequent verse he demonstrates...". This emendation removes the single example cited by Thurneysen ( $\mathrm{p} 225 \$ 355$ ) and Greene (1974: 192) for a substantivized acc. pl. masc. yo/ya-stem adjective, though there are others.

Standard Old Irish would have isind fers remeperthiu, but already in Old Irish and increasingly in Middle Irish (see Breatnach 1994: 259) there are apocopated examples with is, most frequently before dentals, but also before $f, b$ and even vowels. Examples in Milan are found at $46 \mathrm{c} 19$ and $112 \mathrm{~d} 2$ (isdí for isindi), $110 c_{5}$ (is disiu for isindísiu) and ${ }_{116 \mathrm{~d} 5}$ (is dithrub for isindithrub). The apocopation before non-dentals, as here, appears more commonly with the relative pronoun -a-, e.g. fris.m-biat (Sg. 202b3) or fris.m-ben (Immram Brain \$16).

\section{9a16:}

Thes: $\quad$ i. ní déci asndia d(un)decomnacht. do

i.e. he sees not that it is God who has given it him.

Revised: $\quad$.i. ní déci asndia dudecomnacht. do

i.e. he does not see that it is God who has given it him.

Ascoli gives the text as d::decomnacht, which Thes speculates should be $d(u n)$ decomnacht. The ms. has the expected dudecomnacht, though the tail of the $u$ is slightly longer than usual.

72b10:

Thes: $\quad$ huantárrgud

Not translated.

Revised: huantárrciud

by the causing.

The $g$ of Thes is rather a $c$ with an $i$ written slightly below the line, where it could be interpreted as a tail to a $g$. Comparison with instances of the same word in $47 \mathrm{~b} 4$ and $61 \mathrm{~b} 17$ shows that the writing is similar there and should be read as $c i$.

74d13:

Thes: $\quad$.i. ní berae | siu hua duaid | insalmso | air is du duaid immeairic insalmo [leg. insalmso] etc. 
i.e. thou shalt not take from David this psalm, for it is to David that this psalm is suitable etc.

Revised: $\quad$.i. ní berae | siu hua duaid | insalmso | air is du duaid | immeai|ric insalmso etc.

i.e. you (sg) may not take from David this psalm, for it is to David that this psalm is suitable etc.

The ms. actually reads insalmso, not insalmo, as reported in Ascoli and Thes.

77d3:

Thes: $\quad$ duber som ainm fino dunplaig duber fornech 7 nad fulaing etc.

he gives the name of wine to the affliction that is brought upon a man, and which he does not support etc.

Revised: duber 〈som〉 [leg. duberr] ainm fíno dunplaig duber [leg. duberr] fornech $>n \mid$ ad fulaing etc.

the name of wine is given to the affliction that is brought upon a man, and which he does not endure etc.

As noted in Ascoli, the som in dubersom has been erased (though not totally). Thes includes som without explanation. Here it is assumed that the som was a scribal error and should be excluded from the official text.

82a6:

Thes: $\quad$.i. no nunamailtigi [leg. .i. no nunécmailtigid] Not translated.

Revised: $\quad$ i. no nunecmailtigi [leg. .i. no nunecmailtigid]

i.e. or that you (pl) are insolent.

Though Ascoli and Thes read no nunamailtigi, which they suggest correcting to no nunécmailtigid, the ms. actually has no nunecmailtigi. The top of the $e$ is simply very faint, and the rest of it runs together with the $c$ to give the appearance of an $a$.

82c9:

Not in Thes.

Revised: forcanar

it is taught.

This gloss, in a slightly water-damaged part of the last line, is still legible. It does not appear in Ascoli or Thes.

82d7:

Thes:

huandenci ł. huandianmi....i. ad: :: :a ni fil \{ł bi\} anim comrorcne indib fil (com)ro(rcn)e indib

from innocence or from spotlessness, i.e...... there is (or, there is wont to be) no spot of error in them.

Revised: $\quad h u a n d e n c i ł . ~ h u a n d i a n m i . i . ~ a d a r a ~ a n i ~ f i l|\{t b i\}|$ anim $\mid$ comro|rcne $\mid$ indib

from innocence or from spotlessness, i.e...... there is not (or, there is not wont to be) a spot of error in them.

Thes notes that fil (com)ro( $\mathrm{rcn})$ e indib "seems to be an erroneous repetition of the foregoing words". It is unclear how the claimed dittography was arrived at, since it does not appear in the ms. or in Ascoli. 
The additional letters legible under UV light unfortunately do not yield a coherent gloss. It is unclear what emendation to make.

83a5:

Thes: $\quad$ i. etbert orgi du dia

i.e. to bid God arise.

Revised: $\quad$.i. eibert [leg. erbert] ergi du dia

i.e. making use of the arising by God.

Both Ascoli and Thes give the first word as etbert, a strange writing for eibert. It should actually be read as eibert. One might assume that this belongs to epert "saying", but the writing with $b$ is rare (3 of 41 occurrences in Milan) and the glide vowel $i$ never appears after $e$ in this word (though aipert occurs in 5ob8). It is more likely that eibert is a mistake for erbert. Further, the word appears above Latin gloss utitur, and ar.beir and erbert frequently gloss utor.

\section{5b15:}

Thes: duchrech [leg. duchrecha]

Not translated.

Revised: duchrecha

who feigns.

Thes and Ascoli simply misread the ms., which has ducrecha as expected.

86c13:

Thes: $\quad$ i. pro fero ł. pro ferebam .i. fulungáin

Not translated.

Revised: $\quad$.i. pro fero 1. pro ferebam .i. fulungáin|se

i.e. that I used to endure.

-se not in Ascoli or Thes. It is on the line below the rest of the text, and perhaps Ascoli took it to be Latin $s e$.

87d8:

Thes: $\quad$ i. huan chlith on són centabairt dait siu dufortachtae dinni i.e. by concealment, so as not to give Thy help to us.

Revised: $\quad$.i. huan chlith on són centabairt dait siu dufortachtae |dúnni

i.e. that is, by concealment, without You (sg) giving us Your (sg) help.

Either on or són is superfluous (but see 105a2). Thes read dinni, but there is an extra minim faintly present, so that dúnni is the ms. reading. Ascoli suggests that it is rather dim or possibly dunni.

88a4:

Thes: $\quad$.i. is firien dait siu indigal dumbir fornni dég arpectha

i.e. Thou art justified in the punishment which Thou inflictest on us because of our sins.

Revised: $\quad$.i. is firien dait siu adoe | indigal dum|bir fornni $\mid$ dég arpec|tha

i.e. the punishment which You (sg) inflict on us because of our sin is just for you, O God.

adce missing from Thes, though it is present in Ascoli. 
88a9:

Thes:

acht arroissiursa

Not translated.

Revised: $\quad$ acht arroissisiursa

but I remained.

Thes has arroissiursa, adopting Ascoli's original reading, not his corrected reading in the Corrigenda, which Hull (1961: 261) misinterprets as an emendation. The form as in the ms. is the expected one, conforming to Schumacher's analysis (2004: 571ff.), though he does not mention this form specifically.

88b2:

Thes:

i. mencigite

i.e. that are frequent.

Revised: $\quad$.i. mencigtoe

i.e. that are frequent.

Both Ascoli and Thes give the ms. reading as .i. mencigite, but the more likely (and more regular) reading is .i. mencigtoe.

88d6a:

Not in Thes.

Revised:

\section{i. inegipt}

i.e. in Egypt.

This gloss does not appear in Ascoli or Thes. Ascoli apparently viewed it as Latin, but its lack of a case ending suggests it is not Latin (in Egipto would be expected; see the Latin text accompanying 46b22). It is Old Irish, parallel to cases like 63a4, 77d16, etc.

92c7:

Thes: $\quad$.i. dutabairt fortach [leg. fortachtae] doib indairi

i.e. to give them help in captivity.

Revised: $\quad$ i. dutabairt fortach [leg. fortachtae] doib indassa

i.e. to give them help now.

The text here follows Ascoli's suggestion in his Corrigenda that the last word could also be read indassa. The latter reading seems more likely as the ms. reading and also semantically in the context of past benefits and present circumstances.

94d1:

Latin: $\quad$ expertis iam fretisque ${ }^{1}$ auxilis

Thes: $\quad$.i. ambat $n$ airbirthi biuth

i.e. when they shall be enjoyed.

Revised: $\quad$.i. ambat $n$ airbirthi biu|th|::::ón

i.e. when they will be enjoyed.

The text following biuth, although not entirely legible, is not in Ascoli or Thes. There appear to be four or possibly five minims preceding the ón. Obscuring the reading is the fact that the liis of Latin auxiliis from the commentary has been erased and placed on the following line, and ::::ón has been written over the erasure. It is unclear what was intended.

The gloss is a misunderstanding of the Latin: the glossator took fretis "relying on, supported by" as frutis "having enjoyed, consumed". Perhaps he translated the object 
of fretis, i.e. auxiliis, as well, in which case something like ditin "protection" might be expected. This is speculation, however.

96a13:

Thes: $\quad$ i. arndermat (ni di)arsoirad..

i.e. our being forgotten to be delivered.

Revised: $\quad$.i. arndermat|atn arsoir|ad [leg. arndermat narsoirad]..

i.e. forgetting us for deliverance.

While Thes suggests arndermat (ni di)arsoirad, the ms. fairly clearly reads as above. See DIL (Degras-dúus-40.13) for the uncommon construction of dermat with the preposition.

97c1:

Thes: $\quad$ i. coní intamlammar

i.e. that we may not imitate.

Revised: $\quad$ i. coní intamlammarni

i.e. that we may not imitate.

It appears as if $-n i$ was appended to the gloss. It is extremely faint, but this probably does not indicate an erasure. It does not appear in Ascoli or Thes.

10ob16:

Thes: $\quad$.i. robói fomám augairi aili 7 cuarór

i.e. he had been subject to another shepherd and at his will.

Revised: $\quad$.i. robói fomám augairi aili 7 fuarár

i.e. he had been subject to another shepherd and at his will.

Both Ascoli and Thes give the text as cuarór, but it appears that the initial letter is $f$. DIL (R-59.23) suggests this as well, although it is unclear on what basis. Only the upper half of the $f$ is visible, making it look much like a $c$, but it sits too high on the line to be a $c$. If it were actually part of an $f$, such a position would make sense.

102a15:

Thes:

.i. itius anuas dusclaid anis etc.

i.e. they (the passers-by) eat it from above, he (the wild boar) roots it up from below etc.

Revised: $\quad$.i. itius $\mid$ anuas $\mid 7$ duscla|id anis $\mid$ etc.

i.e. he (the wild boar) eats it from above and roots it up from below etc. The translation in Thes "they (the passers-by) eat it from above, he (the wild boar) roots it up from below" is based on an analysis of itius as ithit-us, i.e. a $3 \mathrm{pl}$ verb, which is impossible. Once it is seen that the verb is 3 sg and that there is an ocus between the two clauses, a change of subject (i.e. "he (the passer-by) eats it from above and he (the boar) digs it up from below") without any overt marking to that effect is no longer likely. Additionally, one could translate anuas as "above" and anis as "below", which means that the boar need not eat the vine from above but rather simply eat the vine which is above, a simpler task for an animal located rather close to the ground.

102d17:

Thes:

AMal rusoirtha som hisleib sina tritogair innanmae [leg. trithogairm nanmae] doe etc. 
as they were delivered on Mount Sinai through calling on the name of God etc.

Revised: $\quad$ Amal ru|soirtha $\mid$ som his|leib sina $\mid$ tritogair|m nanmae $\mid$ doe etc.

as they were delivered on Mount Sinai through calling on the name of God etc.

Ascoli's and Thes' reading tritogair innanmae is probably due to the fact that the $m$ is on the following line with nanmae, making one think it belongs with it. Additionally, $m$ can be easily mistaken as $i n$.

110a5-6:

Latin: $\quad$ ut pateret ${ }^{5}$ ad incursús hostium uel Templum ${ }^{6}$ uel populus, ammouisti id pro [leg. per] quod sepiri consuerat atque moniri adiutorio scilicet dei.

Thes: $\quad$ co arosailced i. combad erlam

that it should open, i.e. that it should be ready.

Revised 5: $\quad$ co arosailced

that it should open

Revised 6: .i. combad erlam

i.e. that it should be ready.

The glosses are widely separated in the ms. and should be separated, as recognized by Ascoli. Thes puts both glosses with pateret.

110d15:

Thes: $\quad$ i. arattú centosach cenforcenn

i.e. for Thou art without beginning, without end.

Revised: $\quad$ i. aratái centosach cenforcenn

i.e. for You (sg) are without beginning, without end.

Ascoli and Thes read attú. Bergin suggests emending to attá to avoid the difficult syntax of attú ( 2 sg copula $a t+t u$ ), but the switch to third person is awkward. The reading atái solves all the difficulties and fits better with the fact that at.tá is never written with double $t$ in Milan. The single $t$ is also more common in Würzburg.

116b7-9:

Thes: $\quad$ i. ninant nephatdanaigthe acht is atdanigthe .i. air soilsigthir anaim ind firiéin trí degnimu

i.e. not that it is unremunerated, but it is remunerated; i.e. for the soul of the righteous is illuminated through good works.

Revised 7-8: .i. ninant nephatdanaigthe acht is at|danaigthe

i.e. not that it is unremunerated, but it is remunerated.

Revised 9: $\quad$.i. air soilsigthir anaim ind firiéin trí degnimu

i.e. for the soul of the righteous is illuminated through good works.

The ms. has is atdanaigthe, as in Ascoli, not is atdanigthe, as in Thes. Furthermore, Thes combines this gloss with the following one. This is not justified by the ms., since gloss 9 appears on a different line from glosses 7 and 8 .

116d5:

Thes: atcomforaitmiti [leg. -foraithmiti] .i. ingnima dorigni dia erriu som incegipt :: [leg. nó?] is dithrub [leg. isindithrub] 
that they are to be commemorated, i.e. the works which God had done for them in Egypt, or in the wilderness.

Revised: $\quad$ atacomforaitmiti [leg. -foraithmiti].i. | ingnima | dorigni d|ia erri|u som in|cegipt.. :: | is dithr|ub

that they are to be commemorated, i.e. the works which God had done for them in Egypt. In the wilderness.

The ms. has atacomforaitmiti, as in Ascoli, not atcomforaitmiti, as in Thes. Thes reads inoegipt :: and suggests supplying nó 'or'. Ascoli reads inoegipt.. ::, which is all that can be read now. The indecipherable text is almost certainly not nó. In any case, the double period following inogipt makes a direct continuation somewhat unlikely. The exact connection of is dithrub with the previous text is no longer recoverable, so it will simply be left as it is.

Standard Old Irish would have isin dithrub, but already in Old Irish and increasingly in Middle Irish (see Breatnach 1994: 259) there are apocopated examples with is, most frequently before dentals, as here, but also before $f, b$ and even vowels. Examples in Milan are found at $46 \mathrm{c} 19$ and $112 \mathrm{~d} 2$ (isdí for isindi), $110 c 5$ (is disiu for isindisiu) and $69 \mathrm{a}_{4}$ (is fers for isind fers).

118d10:

Thes:

.i. cetheoira aicsin adfét som sunt sís araneirnestar (?) $d(o) i b s o m$ aracotar do(ath) chumt $(u)$ ch atír

i.e. four causes he sets forth here below for which it should be expected by them that their land might be obtained for rebuilding.

Revised: $\quad$.i. cetheoira aicsin adfét som | sunt sís | ara|neirm|estar |d(o)ibsom [add. $\nmid(?)]$ araco::es|tar [leg. aracoimestar] doat $(\boldsymbol{h}) \mid$ chumtu|ch atíre

i.e. [it is] four causes that he sets forth here below because of which it should succeed for them or because of which it is possible to rebuild their land.

This gloss poses a number of difficulties, most of which come from the interpretation of the two verbs araneirmestar and araco::estar. Thes' reading, following Ascoli, of the forms is araneirnestar and aracotar. The latter of these is unlikely, since it would require a verb ar.cota (in nasalizing relative construction), but ar.cota is a poorly attested replacement of ad-cota. The correct reading is unfortunately unsure, but the suggestion aracoimestar, $s$-subjunctive of con.icc after $a r a^{\mathrm{N}}$, seems plausible formally and semantically (see DIL C-445.34-49 for subjunctive forms). The reading araneirmestar (to ar.midethar) rather than araneirnestar (to ar.nëat) seems assured, since there are three minims visible for the letter in question.

There is room for a letter or possibly two after doibsom, although it must be acknowledged that nothing is legible in the ms. at that point. It is possible to make sense of the gloss without the suggested [add. $1(?)$ ], along the lines of "...it should succeed for them to be possible to have their land rebuilt", but the sense is much more straightforward with nó.

The reading atire is clear from the ms.

118d11:

Thes: $\quad$.i. inlogud étite .i. adeilciud asindoiri ón

i.e. the desire obtained, to wit, their release from the Captivity. 
Revised: $\quad$.i. inlogud ét::e [leg. étto] .i. adelciud asindoiri|ón

i.e. the obtained obtainment, i.e., that is, their release from the Captivity.

While étite is given by both Ascoli and Thes as the ms. reading, there are some problems here. Assured is ét::e, but the middle part of the word is difficult, not because it is hard to read, but because the letters do not correspond well to any particular reading. Possible are étite, éttoe and étae, but each of these contains difficulties. The first possible reading, étite, is the most likely one given the ms., but étite is not a word in Old Irish. On the other hand, éttoe or étae are possible spellings of éttae (which is surely the intended lexeme), but these readings are a little more forced, though not highly so. In the end, the suggestion to read éttoe is simply a convenience, since one must adopt a reading; it should not be construed as being necessarily better than étae. Both are found in Milan (étae at 129az and ettoe at 43b8). Additionally, adelciud, as in Ascoli, is the correct reading, not adeilciud, as in Thes.

\section{8d15:}

Thes: $\quad$ combúmithich ateilciud as indoiri ón so that it were time that they should be released from the Captivity.

Revised: $\quad$ combumithich ateilciud as ind(oiri) so that their release from the Captivity was timely.

Ascoli reads here combumithich ateilcud asind:si ó::, but it appears he has taken the síc of the following gloss and interpreted it as si ó, around which are indeterminate letters. Once this error is corrected, the ón postulated by Thes must be removed. Furthermore, there is simply not room on the ms. page for all the letters proposed by Thes.

118d16:

Thes: $\quad$ trisaccuis insin. that is the third cause.

Revised: $\quad$ trisaccuis anisiu.. síc

this is the third cause, sic.

sic (read as si ó by Ascoli and attached to the previous gloss; see above) must belong here or, less likely, with the previous gloss.

118d17:

Thes: $\quad$ i. terrae repromisionis .i. hírobae $h u(a)$ tha $(d)$ :::: isra ::

i.e. in which there had been few....

Revised: $\quad$.i. terrae repromisionis .i. hírobae hua|thad $\mid$ don(aib)|isra(eldaib)

i.e. in which there had been few of the Israelites.

The Old Irish is very faded. Ascoli reads hírobae hu::tha:doir: isra.. Thes has hírobae $h u(a) t h a(d)::::$ isra :: and suggests that perhaps macn israhel should be supplied. Under UV light more text is legible. Ascoli's doir: is clearly not correct, as the $i$ is obviously the beginning of a letter, probably $n$. It is unclear whether don(aib) isra(eldaib) is right (note that donaib for more correct dinaib is not uncommon in Milan), or even how many letters may be missing. Nonetheless, the reading suggested above is quite plausible.

118d19: 
Thes:

.i. is ed dorat foraib accubur tuid(ech)tae ath(irriuch) $d u(c) h$ (um ati)re $::$ an ::: la ::: he ::: bat :: $r$

i.e. it is this which had inspired them with the desire to come again to their land.......

Revised: $\quad$.i. is ed dorat foraibsom accobur tuid(ech)|tae do | ath(i)r(riuch) | duch(um ati)|(re) :: | anech | la::: ar:: l|a:: | hua: | batar [leg. huam batar]

i.e. it is this which had given them desire of coming again to their land... from which they were.

-som was left out by Thes. The do in tuid(ech)tae do ath(i)r(riuch) is not in Ascoli or Thes, but appears to be the correct reading. I cannot find the re of (ati)re as read by Ascoli, but I assume he was correct. The rest, other than the last two words, is simply too fragmentary to make a solid suggestion.

120d2:

Thes:

.i. amal duneclan [leg. duneclannar] etach $\dot{n}$ derscaigthe hitig cennaig $(i)$ dobuith im(m)ríg is s(amlaid) duérglas soilse sainriud asnaib dulib do imthimchiull in choimded

i.e. as a garment of surpassing excellence is sought out in the house of a merchant to be about a king, so there has been sought out from the elements a special radiance to surround the Lord.

Revised: $\quad$.i. amal duneclan [leg. duneclannar] etach $\dot{n} \mid$ derscaigthe hi|tig cennaigi | dobuith imm(i)n|ríg issaml(aid) | duérglas :: [leg. in (?)] | soilse sain|riud asna|ib dulib do im|thimchiull | in choim|ded

i.e. as a garment of surpassing excellence is sought out in the house of a merchant to be about the king, it is so that the radiance in particular has been sought out from the elements to surround the Lord.

Thes noted that between im and ríg was space for a letter or two. They did not, however, note that there appear to be two letters after duérglas. This nearly illegible smudge appears to have something that could be an $n$ (or an $h$ ), which makes plausible the suggestion of the definite article. While int would be expected as nom. sg. before fem. soilse, the Milan Glosses often enough contain errors concerning the final consonant of the article (see also GOI p. $295 \$ 468$ ) that this should not be a major hindrance to reading in.

120d3 and d5:

Latin:

AMICTUS LUMINE SICUT UESTIMENTO:, noster sensus diuinam laudat naturam. ut quia nobis luce nihil est proestantius, Deum ait multa luce uelari ${ }^{11}$ tabernacula uendentium ${ }^{1}$ scrutari $\{\text { uel scrutarentur }\}^{2}$ tenduntur

EXTENDENS usque PELLEM:

tanta facilitate magna sunt elimenta creata quanta tumultaria ${ }^{3-5}$ uendentium ${ }^{6}$ scrutantur

Thes d3: $\quad$ soirbithir sin do dia

Thes d5: $\quad$ i. int seilcill ł. inmían chinn .i. amal as soirb anersolcud ade occuinchid neich indi bis tuistin aduloe

Revised: $\quad$.i. int | seilcill ł. | inmían|chinn .i. | amal as soirb | anersolcud | ade occuin|dchid neich indibis soirbithir sin do dia| tuistin aduloe 
i.e. the showcases or the desired purchases (?), i.e. as it is easy to open them in seeking anything in them, creating His elements is that easy for the Lord.

Aside from occuindchid for Thes' occuinchid, Ascoli gives glosses 3 and 5 as they appear in Thes and suggests combining them as given in the revised reading. Thes' gloss 5 is in the center margin, while their gloss 3 (soirbithir sin do dia) extends into the space between two lines of Latin text. This is not normally a problem, but gloss 3 in this case is somewhat separated from the rest of the text by a Latin punctuation mark, which gives the appearance that there are two separate glosses. As a result, Ascoli lists two separate glosses and correctly combines them to give a coherent text, apparently without realizing that they are not really separate in the ms.

As the first part of the gloss is rather obscure (it was left untranslated in Thes), and since its understanding depends on the commentary, which is itself corrupt, a longer digression than usual into the commentary is undertaken here. The text quoted above is Psalm 103:2 with its associated commentary. As noted in Ascoli, the commentary at the end of the first half of the verse, tabernacula uendentium scrutari tenduntur, actually belongs to the commentary to the second part of the verse. Even so, the suggestion in Thes is not satisfactory.

Adkin (2000) examines the problem and proposes that the commentary to this and the previous verse (Psalm 103:2) should read:

AMICTUS LUMINE SICUT UESTIMENTO

noster sensus diuinam laudat naturam. ut quia nobis luce nihil

est prostantius, Deum ait multa luce uelari

EXTENDENS usque PELLEM

tanta facilitate magna sunt elimenta creata quanta tumultuaria tabernacula uendentium scruta retenduntur

The commentary to EXTENDENS... PELLEM then means "with as much great ease are the elements created as the make-shift tents of those selling odds and ends are taken down".

This text was unfortunately not in front of the glossator, for whom tumultaria (= tumultuaria), was unclear. His text must mean something like "with as much great ease are the elements created as tumultuaria of merchants are examined / searched". It seems that he assumes tumultuaria to be some item, belonging to merchants, which can be opened easily.

The compounds seilcill and míanchinn are nominative plurals, but their composition is not straightforward. The suggestion offered here is that seil- belongs with sellaid "sees, gazes" or sillid "id." and -cill to cell "church" here in an extended use as "enclosure, case". seilcill would thus be "showcases". mían- must be "desire" and chinn may be from cenn "exchange" (base of cennach "id."). There are numerous problems with these suggestions: the gender of the compounds is masculine, but cell is feminine and cenn neuter; the assumption of cenn "exchange" is possible, given cennach, but not assured; seil- would not be expected in a compound, rather sil- or sel-. Despite these problems, no better solution has yet presented itself.

123c10:

Thes: $\quad$ i. ataidchrec co sommataid 7 setaib leu is huilliu són :: indaas bid leu censommataid [leg. censommataid leu] doaithchretis 
i.e. their redemption with wealth and treasures with them, that is more than if they had been redeemed without wealth with them.

Revised: $\quad$.i. ataidchrec co sommataid 7 setaib leu | is huilliu són |didiu indaas bid |censomataid leu | doaithchretis

i.e. their redemption with wealth and treasures with them, that is then more than if they had been redeemed without wealth with them.

The reading of the didiu (which Thes said looked like si) is assured. The order of censomataid leu is somewhat ambiguous in the ms., but the revised ordering (suggested in any case by Thes as the intended one) is more likely.

\section{6b15:}

Thes: $\quad$.i. it cosmaili anargumeinti

i.e. their arguments are similar.

Revised: $\quad$.i. it cosmaili anargumenta

i.e. their arguments are similar.

Under UV light, the last word of the ms. can be read as anargumenta, i.e. as a Latin word, not an Old Irish one.

\section{6d8a:}

Thes: $\quad$ foncécnae [leg. foncétnae] $\quad \dot{n}$ dul són according to the first way.

Revised: $\quad$ foncét $\mid$ nae $\dot{n} \mid$ dul són that is, according to the first way.

Ascoli, followed by Thes, misread the first word and suggested the correction as above. In fact, the ms. needs no correction when correctly read.

128c7:

Thes:

.i. bid foraithmetach ón atairngeri i. ní cuit ataidbsen nammá cenachomallad ingnim(aib) op:-

i.e. He will be mindful of His promise, i.e. not as to shewing it only without fulfilling it in deeds.

Revised: $\quad$ i. bid foraithmet|ach ón | atairngeri | i. ní cuit | ataidbsen | nammá cena|chomallad in|gním(:) op.., [leg. in opus (?)]

i.e. that is, He will be mindful of His promise, i.e. it is not only a matter of showing it without fulfilling it in deed.

Thes reads the end of the gloss as ingnim(aib) op:, suggesting that operibus was intended. It appears to my eye rather to read ingnim(:)op... In this case, gnim is probably singular, since there is not enough room for $a i b$. How to interpret the last letters is admittedly difficult. It will be assumed here that in opus was written (cf. $101 \mathrm{c11}$ where in opus is glossed by .i. corroib ingnim 'i.e. that it may be in action.').

13ob8:

Thes: $\quad$ asroilli i. ised as maith ladia airimp isin ges ::::::: dilg(u)d i.e. this God would have...... forgiveness.

Revised: $\quad$ asroilli.i. ised as maith ladia air|imp isin |gessae in $\mid \operatorname{dilg}(u) d$ you (sg) are entitled, i.e. it is this which is good in the eyes of God, that it be here that the forgiveness was asked for. 
The reading as above is the best possible reading, although the degree of confidence in it is low. One might argue for gesst:: instead of gessae. The tentative suggestion of Thes to read airimp isiu gessit andilgud 'that they should pray here for their forgiveness' uel. sim. comports relatively well with the revised reading and meaning given here, though the past tense is odd.

\section{Bibliography}

Adkin, Neil. 2000. "Julian of Eclanum on Psalm 103:2". Journal of Theological Studies 51/1: 161-3.

Ascoli, Graziadio Isaia. 1878-9. Il Codice irlandese dell'Ambrosiana [= Archivio glottologico 5-6], Roma: Ermanno Loescher.

Best, Richard I. 1936. The Commentary on the Psalms with glosses in Old-Irish preserved in the Ambrosian Library (MS. C 301 inf.). Collotype facsimile, with Introduction, Dublin: Royal Irish Academy.

Breatnach, Liam. 1994. “An Mheán-Ghaeilge”. In Stair na Gaeilge, edd. Kim McCone, Damian McManus, Cathal Ó Háinle, Nicholas Williams, Liam Breatnach, 221333. Maigh Nuad: Roinn na Sean-Ghaeilge, Coláiste Phádraig.

Greene, David. 1974. "Distinctive plural forms in Old and Middle Irish". Ériu 25: 1909.

Hull, Vernam. 1961. "Old Irish sissidir and its compounds." ZCP 28: 260-1.

McCone, Kim. 1985. "The Würzburg and Milan glosses: our earliest sources of 'Middle Irish.” Ériu 36:85-106.

Sarauw, Christian. 1900. Irske Studier. Copenhagen: Det schubotheske Forlag.

Schumacher, Stefan. 2004. Die keltischen Primärverben. Innsbruck: IBS. 